\title{
Livonian Canons and Challenge of the Reformation
}

\author{
M. Maasing
}

For citation: Maasing M. Livonian Canons and Challenge of the Reformation. Vestnik of Saint Petersburg University. History, 2019, vol. 64, iss. 3, pp.996-1013.

https://doi.org/10.21638/11701/spbu02.2019.311

The article examines five Livonian cathedral chapters - Riga, Dorpat, Osilia, Curonia and Reval - during the Reformation era (1522-1566): from the beginning of Livonian Reformation to the dissolution of the Chapter of Riga. The main aim is to identify the most important changes in the chapters, and to examine reactions to the Reformation and to the religious alterations amongst the canons. Although there are obvious gaps in the statistical data, it is possible to present an overall picture of the situation. If one compares the beginning and the end of the period, the numbers of the canons seem to have remained almost the same. The number of local canons that came from burgher families drops which could be connected with the success of the Reformation in Livonian towns, while the increase in the number of canons from Germany might be connected to the intensifying relations of Livonia with the Holy Roman Empire. The falling number of cumulations (i. e., cases when a canon held multiple chapter seats simultaneously) might indicate pursuit to enhance internal discipline in the chapters and attempt to face the challenge of the Reformation. The data about religious affiliations shows that the chapter of Riga was dominantly Catholic at the end of the 1540s, but mainly Protestant by the end of the 1550s. Generally, it appears that there were no serious confessional conflicts in Livonian chapters, and as there is no information about them elsewhere, it can be concluded that confessional conflicts reached Livonia only during and after the Livonian War.

Keywords: Reformation, cathedral chapters, canons, Medieval Livonia, Teutonic Order, Archbishop Wilhelm of Riga.

\section{Ливонские каноники и вызов Реформации}

\section{М. Маазинг}

Для цитирования: Maasing M. Livonian Canons and Challenge of the Reformation // Вестник Санкт-Петербургского университета. История. 2019. Т. 64. Вып. 3. С. 996-1013. https://doi.org/10.21638/11701/spbu02.2019.311

В статье рассматриваются пять ливонских кафедральных капитулов five Livonian cathedral chapters - Риги, Дерпта, Эзеля, Курляндии и Ревеля в эпоху Реформации (1522-1566): от начала Реформации Ливонии до роспуска капитула Риги. Основная

Madis Maasing - PhD, Research Fellow, University of Tartu, 18, Ülikooli, Tartu, 50090, Estonia; madis.maasing@ut.ee

Мадис Маазинг - д-р философии, науч. сотр., Тартуский университет, Эстония, 50090, Тарту, Юликоли, 18; madis.maasing@ut.ee

The research carried out for this article has been supported by the Estonian Research Council (grant PUT1422).

Исследование, выполненное для этой статьи, было поддержано Эстонским научным советом (грант PUT1422).

(c) Санкт-Петербургский государственный университет, 2019 
цель - показать наиболее важные изменения в капитуле и выяснить реакцию на Реформацию и религиозные изменения, происходящие среди каноников. Несмотря на очевидные пробелы в статистических данных, можно представить общую картину. Если сравнивать начало и конец периода, то число каноников, вероятно, осталось практически неизменным, но количество местных каноников, происходивших из семей бюргеров, уменьшилось, что может быть связано с успехом Реформации в ливонских городах, в то время как увеличение числа немецких каноников может быть связано с усилением контактов Ливонии со Священной Римской империей. Падение числа кумуляций (т.е. случаев, когда каноник занимал в капитуле одновременно несколько мест) может указывать на стремление повысить внутреннюю дисциплину в капитуле и принять вызов Реформации. Данные о религиозной принадлежности показывают, что рижский капитул в конце 1540-х гг. был преимущественно католическим, в то время как к концу 1550-х гг. - в основном протестантским. Таким образом, вероятно, что в ливонском капитуле не было серьезных конфессиональных конфликтов, и, поскольку об этом нет никаких свидетельств и в других местах, можно сделать вывод, что конфессиональные конфликты достигли Ливонии только во время и после Ливонской войны.

Ключевые слова: Реформация, соборный капитул, каноники, средневековая Ливония, Немецкий орден, архиепископ Рижский Вильгельм.

The Reformation has often been considered one of the most important historical processes, but at the same time also one of these that was especially complex. Its canonical starting point (31 October 1517) has been frequently regarded as the end of Medieval Times and the beginning of Early Modern era. On the other hand, most of its effects and outcomes that encompassed not only religious but also eminent political, social and cultural changes became evident only decades later. Then, a clear division between Catholicism and Protestantism emerged, and thus began the period that in recent decades has been often labeled the era of confessionalism or confessionalization. During this period, questions of faith and especially religious differences often played a key role in social and political life ${ }^{1}$.

The introduction of the Reformation was especially complicated in Livonia (which consisted of present-day Estonia and Latvia). The so-called Evangelical Faith began to spread in the early 1520s, and it was embraced by most of the Livonian towns within a decade. At the same time, however, previous political system of Livonia and most of its religious institutions were preserved until the Livonian War (1558-83), during which the land was subjugated to and divided by foreign powers. However, the Reformation did not leave the political elites untouched, and by the end of the 1550s, most of them were supporting Lutheranism².

There are no exhaustive studies on the course of Livonian Reformation after the year 1533 when Lutheranism consolidated in three most important cities - Riga, Reval (Tal-

${ }^{1}$ See, e.g.: Die lutherische Konfessionalisierung in Deutschland. Wissenschaftliches Symposion des Vereins für Reformationsgeschichte 1988 / ed. by H.-C. Rublack. Gütersloh, 1992; Konfessionalisierung in Ostmitteleuropa. Wirkungen des religiösen Wandels im 16. und 17. Jahrhundert in Staat, Gesellschaft und Kultur / eds J. Bahlcke, A. Strohmeyer. Stuttgart, 1999; Interkonfessionalität - Transkonfessionalität binnenkonfessionelle Pluralität. Neue Forschungen zur Konfessionalisierungsthese / eds K. von Greyerz, M. Jakubowski-Tiessen, T. Kaufmann, H. Lehmann. Gütersloh, 2003.

${ }^{2}$ E.g., a vast majority of Livonian princes and estates supported the Reformation in March 1558: Briefe und Urkunden zur Geschichte Livlands in den Jahren 1558-1562. Vol. 1 / ed. by F. Bienemann. Riga, 1865. No. 73, 75-77, 80-81, 88. 
linn) and Dorpat (Tartu), ${ }^{3}$ and thus, it has remained largely unclear how successfully dissemination of the Lutheran faith took place outside of urban society. At least until the 1550s, it is hard to deduce general religious affiliations among Livonian territorial lords (German Landesherren) who were Catholic dignitaries and secular rulers at the same time - the Archbishop of Riga, the Bishops of Dorpat, Osilia (Ösel-Wiek) and Curonia, and the Livonian branch of the Teutonic Order ${ }^{4}$. The same applies to their estates (German Stände): cathedral chapters (German Domkapitel), nobility, and towns that also played an important role in politics ${ }^{5}$. It is especially complicated to say anything about rural dwellers as there is very little information about the nobility, and the data concerning Livonian peasantry is even scarcer ${ }^{6}$.

There is, however, a Livonian elite group about whom we have somewhat more data: namely, about the members of cathedral chapters or the canons (German Domherren) of Riga, Dorpat, Osilia, Curonia, and Reval (Tallinn). Thus, they are in the main focus of this paper. The chapters - councils of clerics that resided by the cathedrals - were not only religiously but also socially and politically relevant institutions. Canons took care of religious sermons, counseled bishop in ecclesiastical matters, and elected bishops who frequently originated amongst themselves. Seat of a canon in a chapter also meant a right for certain income: a benefice (Latin prebendum, German Pfründe) which provided quite substantial upkeep and allowed prestigious lifestyle for its holder. The canons also had eminent positions in the secular administration of a Prince-Bishopric: at least some of them were members of bishopric's highest judicial and governing body - its council (German Stiftsrat). In Livonia, canons also participated in the Diet (German Landtag) the forum, where Livonian lords and estates convened to discuss and decided over the most important political issues ${ }^{7}$.

${ }^{3}$ Detailed survey in the monograph by Leonid Arbusow Jr. - which has remained the most important study about Livonian Reformation, despite its age - concludes with the year 1533 (Arbusow L. Jr. Die Einführung der Reformation in Liv-, Est- und Kurland. Leipzig, 1921).

4 The Bishop of Reval had only ecclesiastic and no princely power. There is solid information about two Livonian lords that had been supporting Lutheranism before the 1550s, Arcbishop Wilhelm of Riga, and Master Hermann von Brüggenei: Müller U.: 1) Erzbischof Wilhelm von Riga und die Reformation in Livland 1535-1563 // Preußen und Livland im Zeichen der Reformation / eds A. Mentzel-Reuters, K. Neitmann. Osnabrück, 2014. P. 241-343; 2) Herzog Albrecht in Preußen und Erzbischof Wilhelm von Riga in ihren Bemühungen um die Evangelisierung der Landbevölkerung Livlands, I-III // Preußenland. N. F.. 2014. Vol.5. P. 49-97; 2015. Vol.6. P. 43-99; Kreem J. Der Deutsche Orden in Livland unter Hermann von Brüggenei: Bemerkungen zu Regierungspraxis und Religionspolitik // Ordines Militares. 2011. Vol. 16. P. 303-315.

5 Piirimäe P. Ständischer Dualismus und territoriale Verselbständigung. Über der Verfassung des Bistums Dorpat im letzten Jahrhundert Alt-Livlands // Zur Geschichte der Deutschen in Dorpat / eds H. Piirimäe, C. Sommerhage. Tartu, 1998. P. 38-62; Lange T. Zwischen Reformation und Untergang Alt-Livlands: Der Rigaer Erzbischof Wilhelm von Brandenburg im Beziehungsgeflecht der livländischen Konföderation und ihrer Nachbarländer. Vol. I-II. Hamburg, 2014. P.74-101; Maasing M. The Role of the Bishops in the Livonian Political System (in the First Half of the $16^{\text {th }}$ Century). Tartu, 2016.

${ }^{6}$ There is more information only since the end of the $16^{\text {th }}$ century, see: Loit A. Reformation und Konfessionalisierung in den ländlichen Gebieten der baltischen Lande von ca. 1500 bis zum Ende der schwedischen Herrschaft // Die baltischen Lande im Zeitalter der Reformation und Konfessionalisierung: Livland, Estland, Ösel, Ingermanland, Kurland und Lettgallen: Stadt, Land und Konfession 1500-1721. Vol. 1 / eds M. Asche, W. Buchholz, A. Schindling. Münster, 2009. P. 49-217.

7 There are many studies about German chapters that give good overview about the main traits of the chapters. Here are named only three of them that gave especially useful background information for current study: Fouquet G. Das Speyerer Domkapitel im Späten Mittelalter (ca. 1350-1540): adlige Freundschaft, fürstliche Patronage und päpstliche Klientel (Teil I). Mainz, 1987; Braun H. A. Das Domkapitel zu Eichstätt: 
The Reformation affected chapters critically, and, as they were tightly bound to the Catholic Church, the success of the so-called new faith threatened their existence. Thus, it is not surprising that German researchers of the Reformation era have found that the chapters were among the most persistent opponents to the religious renewal, and sometimes, the canons were even able to halt the official introduction of the Reformation ${ }^{8}$. Leonid Arbusow Jr. claimed that similarly to German chapters, the Livonian ones were bulwarks of the Catholicism; especially in the 1540s and 1550s, but he did not elaborate on that much ${ }^{9}$. On the other hand, in regions where Protestantism won, the chapters were also inclined to become Protestant, although it could have taken rather a long time. In Lübeck and its surroundings, the city embraced the Reformation in 1530, but Lutherans formed clear majority in the chapter only by the $1590 \mathrm{~s}^{10}$.

There are no studies whose main topic is the effect of the Reformation on the Livonian chapters, and thus, this article is the first attempt to summarize the knowledge we have about this important elite group during the Reformation era (1522-1566). This era is defined here by two framing events: The beginning of the official support of the City Council of Riga for the "evangelical" preachers and problems with an "evangelical" canon in the Chapter of Riga in 1522; and the dissolution of the chapter of Riga in 1566 - by that time, probably all Livonian chapters had become defunct.

In order to evaluate the actual response of Livonian chapters and canons to the challenge posed by the Reformation, it is necessary to delve into the literature and sources that provide both the individual characteristics of the canons and an overview of the general trends regarding them. The latter is partially provided by general surveys about the chapters of Dorpat ${ }^{11}$, Osilia ${ }^{12}$, and Curonia ${ }^{13}$; and also by my paper that discusses influence of local nobility on the chapter of Osilia during the Reformation period ${ }^{14}$. Several articles concern the chapter of Riga ${ }^{15}$, including the one that discusses a futile attempt to secular-

von der Reformationszeit bis zur Säkularisation (1535-1806): Verfassung und Personalgeschichte. Stuttgart, 1991; Prange W. Der Wandel des Bekenntnisses im Lübecker Domkapitel 1530-1600. Lübeck, 2007.

About Livonian Diet, see: Raudkivi P. Der livländische Landtag: zur Entstehung einer mittelalterlichen Institution. Berlin, 2018; Piirimäe P. Staatenbund oder Ständestaat? Der livländische Landtag im Zeitalter Wolters von Plettenberg // Forschungen zur baltischen Geschichte. 2013. Vol. 8. P. 40-80.

${ }^{8}$ See for example: Wolgast E. Hochstift und Reformation. Studien zur Geschichte der Reichskirche zwischen 1517 und 1648. Stuttgart, 1995. P. 183-195, 267-271.

9 Arbusow L.Jr. Die Einführung der Reformation in Liv-, Est- und Kurland. P. 639.

10 Prange W. Der Wandel des Bekenntnisses im Lübecker Domkapitel 1530-1600.

11 Lukas T. Tartu toomhärrad, 1224-1558. Tartu, 1998.

12 Lukas T. Die Domherren des Bistums Ösel-Wiek 1228-1563 // Saare-Lääne piiskopkond. Artiklid Lääne-Eesti keskajast / ed. by U. Paras. Haapsalu, 2004. P. 211-244.

${ }^{13}$ Hertwich E. Das Kurländische Domkapitel bis 1561 // Die Domkapitel des Deutschen Ordens in Preußen und Livland / eds R. Biskup, M. Glauert. Münster, 2004. S. 147-267.

${ }^{14}$ Maasing M. Kas Saare-Lääne toomkapiitlist sai 1524. aasta järel aadlikapiitel? // Läänemaa Muuseumi toimetised. Vol.21. 2018. P. 33-62.

${ }^{15}$ Kallmeyer T. Geschichte der Habits-Veränderungen des Rigischen Domcapitels, nebst Untersuchungen über streitige Gegenstände in derselben, mit urkundlichen Beilagen // Mitteilungen aus dem Gebiete der Geschichte Liv-, Est- und Kurlands. Vol. 2. 1842. P. 197-340; Mettig C. Zur Verfassungsgeschichte des Rigaschen Domcapitels // Mitteilungen aus dem Gebiete der Geschichte Liv-, Est- und Kurlands. Vol. 12. 1880. S. 509-537; Mettig C. Bemerkungen zur Geschichte des Rigaschen Domkapitels // Sitzungsberichte der Gesellschaft für Geschichte und Altertumskunde der Ostseeprovinzen Russlands aus dem Jahre 1911. Riga, 1913. S. 386-394; Glauert M. Die Bindung des Domkapitels von Riga an die Regel des Deutschen Ordens // Die Domkapitel des Deutschen Ordens in Preußen und Livland. S.269-316. 
ize the chapter by the Archbishop in the $1560 \mathrm{~s}^{16}$. As far as investigating personal traits of the canons are concerned, the main basis is provided by more than century old but still the best and most extensive data collection about Livonian clergy: "Livlands Geistlichkeit vom Ende des 12. bis ins 16. Jahrhundert" by Leonid Arbusow Sr. ${ }^{17}$ Recently published seven-volume "Herzog Albrecht von Preußen und Livland" offers valuable additional information, especially with respect to the chapter of Riga ${ }^{18}$.

The nature of available literature and sources narrows the scope of this study. There are obvious gaps in the information about Livonian canons in the 1530s and 1540s. Moreover, only the name of a canon and the date of his mentioning are often known, but, in most cases, it is possible to, at least, assume his social and geographical background. Finally, the data concerning canons' personal beliefs is scarce, and only for a handful of them something precise can be inferred.

Taking into consideration these limitations, the following topics are observed in the article. A brief overview of the general characteristics of Livonian chapters before the Reformation is followed by a more detailed survey of them during the Reformation era. Here, the analysis covers two main aspects. Firstly, statistical data about Livonian chapters is examined, with the focus on the following questions: were there significant changes in the number of the canons, and in their social and geographical background, and also in their habit to hold multiple chapter seats simultaneously; and if there were important changes, what could have caused them? Secondly, responses of the chapters to the Reformation, and personal religious affiliations of the canons are discussed: did they oppose the religious renewal, embrace it, or were they indifferent?

\section{Livonian chapters on the eve of the Reformation}

At the beginning of the $16^{\text {th }}$ century, the chapters of Livonia offered quite eminent social and political positions and a lifestyle that probably resembled more the one of nobles or wealthy burghers than that of humble monks. Three of five Livonian chapters were secular - the canons did not have common life (Latin vita communis) or common property, but held their benefices individually ${ }^{19}$. The chapters of Riga and Curonia were formally regulated: The canons had to belong to the Teutonic Order as clerical or priest brothers (German Priesterbrüder). Nevertheless, this so-called incorporation into the Order had become mostly nominal by the $16^{\text {th }}$ century. The canons of Riga acted inde-

${ }^{16}$ Lange H. Der Streit zwischen dem Erzbischof Wilhelm und dem Rigaschen Domkapitel wegen der erledigten Propstei 1561 // Mitteilungen aus dem Gebiete der Geschichte Liv-, Est- und Kurlands. 1911. Vol.21. S.30-83.

17 Arbusow L. Sr. Livlands Geistlichkeit vom Ende des 12. bis ins 16. Jahrhundert // Jahrbuch für Genealogie, Heraldik und Sphragistik, 1900 (1902), P.33-80 [Part 1]; 1901 (1902), P.1-160 [Part 2]; 1902 (1904), P. 39-134 [Part 3]; 1911-13 (1914), P. 1-432 [Part 4].

${ }^{18}$ Herzog Albrecht von Preußen und Livland (1525-1534) / ed. by U. Müller. Köln [etc], 1996; Herzog Albrecht von Preußen und Livland (1534-1540) / ed. by S. Hartmann. Köln [etc], 1999; Herzog Albrecht von Preußen und Livland (1540-1551) / ed. by S. Hartmann. Köln [etc], 2002; Herzog Albrecht von Preußen und Livland (1551-1557) / ed. by S. Hartmann. Köln [etc], 2005; Herzog Albrecht von Preußen und Livland (1557-1560) / ed. by S. Hartmann. Köln [etc], 2006; Herzog Albrecht von Preußen und Livland (1560-1564) / ed. by S. Hartmann. Köln [etc], 2008; Herzog Albrecht von Preußen und Livland (1564-1570) / ed. by S. Hartmann. Köln [etc], 2008.

19 Cf. Lukas T. Tartu toomhärrad, 1224-1558. P. 66-70. 
pendently from the Order and held their benefices individually like secular canons ${ }^{20}$. There is little information about internal life of Curonian chapter, but, at least during the Reformation era, there were several canons that did not belong to the Order and had personal holdings ${ }^{21}$. Thus, one could assume that common life had actually disappeared also from that chapter.

In many German bishoprics, local nobles utilized chapters to enhance their social, political and economic position, and often succeeded in reserving chapter seats to themselves during the Late Medieval Times ${ }^{22}$. In Livonia, the only known attempt at this was made in Osilia: in 1524, according to the Bishop's privilege, all future chapter seats were granted to the local nobles, but, as it appears from the statistical data, this attempt was only partially successful ${ }^{23}$.

There were several ways to obtain the desirable position of a canon ${ }^{24}$, but it is actually not known how it functioned in Livonia. Tõnis Lukas has assumed that nomination of new canons was in most cases probably carried out by the canons themselves, which was also very wide spread practice in Germany ${ }^{25}$. On the other hand, Erwin Hertwich stated that, in Curonia, the cooperation between the Bishop and the chapter seemed to be the most common way ${ }^{26}$. There are also indications from Dorpat, Osilia, and Riga that Bishops had a quite important role ${ }^{27}$. In the $14^{\text {th }}-15^{\text {th }}$ centuries, many chapter seats in Livonia were provided by Papal Curia, but this practice was increasingly opposed by the locals, and by the beginning of the $16^{\text {th }}$ century, successful Papal provisions had become quite rare in Livonia ${ }^{28}$. Lastly, one cannot forget the Teutonic Order that had definitely a say concerning at least some seats in the chapters of Riga and Curonia ${ }^{29}$.

\section{Number of canons}

The most common number of the chapter seats in a chapter was 12 (the number of the Apostles), but it depended mostly on the chapter's political, social and economic possibilities, and might change in the course of time ${ }^{30}$. In Dorpat, the maximal number of seats

${ }^{20}$ Mettig C. Bemerkungen zur Geschichte des Rigaschen Domkapitels; Glauert M. Die Bindung des Domkapitels von Riga an die Regel des Deutschen Ordens.

${ }^{21}$ E. g., long-time canon Johann Schnabel (1525-53) had a conflict about his estates with the commander of Goldingen (Kuldiga) in the 1540s (Herzog Albrecht von Preußen und Livland (1540-1551)... No. 1389; Herzog Albrecht von Preußen und Livland (1551-1557)... No. 1605).

22 Fouquet G. Das Speyerer Domkapitel im Späten Mittelalter (ca. 1350-1540): adlige Freundschaft, fürstliche Patronage und päpstliche Klientel. P. 2-4, 26-27, 52-62.

${ }^{23}$ For more detailed overview of this attempt, see: Maasing M. Kas Saare-Lääne toomkapiitlist sai 1524. aasta järel aadlikapiitel?

${ }^{24}$ About general possibilities, see: Fouquet G. Das Speyerer Domkapitel im Späten Mittelalter (ca. 1350-1540): adlige Freundschaft, fürstliche Patronage und päpstliche Klientel. P.34-38; Braun H.A. Das Domkapitel zu Eichstätt: von der Reformationszeit bis zur Säkularisation (1535-1806): verfassung und Personalgeschichte. P. 40-55.

${ }_{25}$ Lukas T. Tartu toomhärrad, 1224-1558. P. 42.

${ }^{26}$ Hertwich E. Das Kurländische Domkapitel bis 1561. P. 212-223.

27 Maasing M. Kas Saare-Lääne toomkapiitlist sai 1524. aasta järel aadlikapiitel? P. 37, 47-48.

28 Cf. Lukas T. Tartu toomhärrad, 1224-1558. P.71-76.

29 Hertwich E. Das Kurländische Domkapitel bis 1561. S. 214-217; Herzog Albrecht von Preußen und Livland (1551-1557)... No. 1672-1673.

30 Fouquet G. Das Speyerer Domkapitel im Späten Mittelalter (ca. 1350-1540): adlige Freundschaft, fürstliche Patronage und päpstliche Klientel. P. 33-34; Lukas T. Tartu toomhärrad... P. 49-50. 


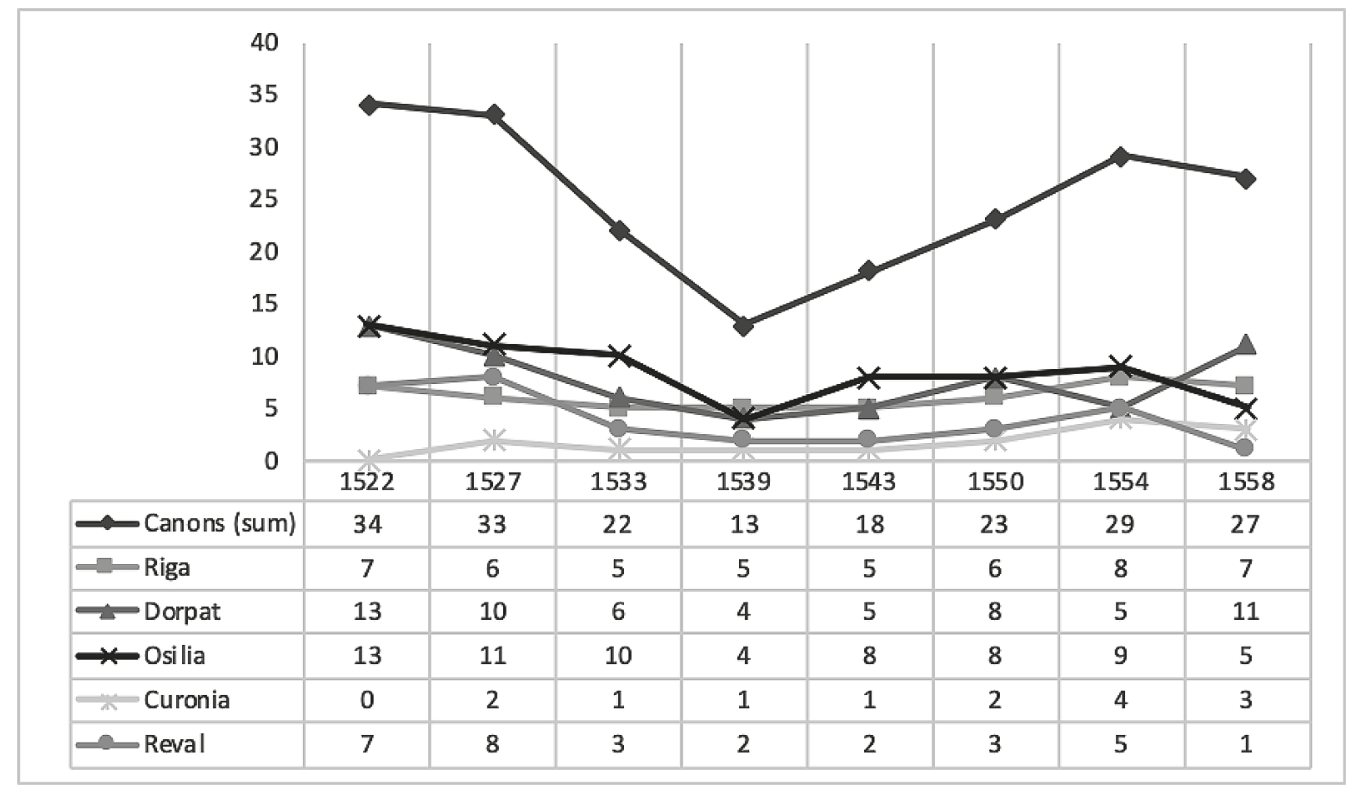

Figure. Livonian canons by year, 1522 to 1558 .

The years to observed were chosen depending on the data available for the concrete year - thus, the pace variates between 4-7 years. Not only the canons directly mentioned in the given year are considered, but also these who were mentioned both before and after that year (e.g., for the year 1522, firstly in 1521 or earlier, and then 1523 or later). Canons that were lastly mentioned in the previous year (e.g., 1521) or firstly in the next (e.g., 1523), were excluded. 1558 was chosen as the last year for it was the ultimate year when all Livonian chapters existed

was probably 20, but it seems that there were usually around 10 canons in the chapter ${ }^{31}$. In Osilia, this number seems to have been quite the same ${ }^{32}$. In other chapters, the figures were lower. In Riga, the number of seats was reduced from 12 to 8 in 1509 or $1522^{33}$. There were only 6 chapter seats in Curonia, but the actual number of canons was usually smaller, and there could be times when there was one single chapter member or even no canons at $\mathrm{all}^{34}$. In the chapter of Reval, the official number was 12 in the $15^{\text {th }}$ century $y^{35}$, but, as it is shown below, it seems that the actual figure was clearly less than 10 .

On the basis of the available data, it was possible to verify altogether 113 Livonian canons for the period of 1522-66. Numbers of canons by each chapter were: 24 in Riga, 41 in Dorpat, 45 in Osilia, 9 in Curonia, and 27 in Reval ${ }^{36}$. If the number of canons is observed by year, there are some significant fluctuations (Figure). During the 1520 s, the

31 Lukas T. Tartu toomhärrad, 1224-1558. P. 50-52.

32 Cf. Lukas T. Die Domherren des Bistums Ösel-Wiek 1228-1563; Maasing M. Kas Saare-Lääne toomkapiitlist sai 1524. aasta järel aadlikapiitel?

${ }_{33}$ Dogiel M. Codex Diplomaticvs Regni Poloniæ Et Magni Dvcatvs Litvaniæ. Vol. 5. Vilnae, 1759. No.XCVI, CII; Mettig C. Bemerkungen zur Geschichte des Rigaschen Domkapitels; Arbusow L.Jr. Die Einführung der Reformation in Liv-, Est- und Kurland. S. 235-236.

${ }^{34}$ Hertwich E. Das Kurländische Domkapitel bis 1561. S.177-197. - In 1519, it was said that the Church of Curonia had no canons, but the position of provost was actually filled (Ibid. P. 178, 185).

35 Liv-, est- und kurländisches Urkundenbuch / ed. by P. Schwartz. Series 1. 1905. Vol. 11, No. 624.

36 The sum of canons by each chapter is distinctively larger than the actual number of canons (146 against 113) because many of them were simultaneously in more than one chapter. 
overall number seems to have been quite stable: there were 34 canons in 1522, and 33 in 1527. Thereafter, the numbers are clearly dropping the year 1539 being the lowest with only 13 known canons. However, the numbers rise again afterwards, and in the 1550s, they do not differ much from the 1520s (29 in 1554, and 27 in 1558). The figures in each chapter fluctuate in more or less similar manner. Generally, one gets impression that the chapter of Osilia normally had the largest number of canons (4 to 13; the mean number for the eight years compared is 8.5) followed by Dorpat (also 4 to 13; the mean is 7.75), Riga ( 5 to 8; the mean is 6.1) and Reval (1 to 8; the mean is 3.875); while the chapter of Curonia had clearly the least canons ( 0 to 4 ; the mean is 1.75$)^{37}$. The number of canons is the most stable in the chapter of Riga which might indicate that we know almost all canons that resided there.

\section{Social and Geographical Background of the Canons}

For the period 1522-1566, the data demonstrate some evident changes in social and geographical origin of Livonian canons. In general, most of the canons whose origin is known were seemingly born in Livonia, and there were more canons from burgher families than from the noble ones ${ }^{38}$. One could claim that the same applies to the period 1522-1566, but if one divides 113 canons between three sub-periods - 35 that came to chapters until $1522^{39}, 39$ that joined the chapters during 1523-48, and 39 that joined

Table 1. Social and Geographical background of Livonian canons, 1522-66

\begin{tabular}{|c|c|c|c|c|c|c|c|c|}
\hline \multirow{2}{*}{ Period } & \multirow{2}{*}{ Canons } & \multicolumn{3}{|c|}{ Social background } & \multicolumn{3}{c|}{ Geographical background } \\
\cline { 3 - 9 } & & Nobles & Burghers & $?$ & Livonia & Germany $^{\star}$ & Poland $^{\star *}$ & $?$ \\
\hline 1522 & $35(100 \%)$ & $11(31,4 \%)$ & $24(68,6 \%)$ & - & $21(60 \%)$ & $6(17,2 \%)$ & $6(17,2 \%)$ & $2(5,7 \%)$ \\
\hline $1523-48$ & $39(100 \%)$ & $18(46,1 \%)$ & $20(51,3 \%)$ & $1(2,6 \%)$ & $22(56,4 \%)$ & $8(20,5 \%)$ & $3(7,7 \%)$ & $6(15,4 \%)$ \\
\hline $1549-66$ & $39(100 \%)$ & $21(53,8 \%)$ & $17(43,6 \%)$ & $1(2,6 \%)$ & $13(33,3 \%)$ & $15(38,5 \%)$ & $2(5,2 \%)$ & $9(23,1 \%)$ \\
\hline $1522-66$ & $\mathbf{1 1 3}(100 \%)$ & $\mathbf{5 0}(44,2 \%)$ & $\mathbf{6 1}(54 \%)$ & $\mathbf{2 ( 1 , 8 \% )}$ & $\mathbf{5 6}(49,6 \%)$ & $\mathbf{2 9}(25,7 \%)$ & $\mathbf{1 1}(9,7 \%)$ & $\mathbf{1 7}(15 \%)$ \\
\hline
\end{tabular}

* There were 26 canons from Northern or North-Western Germany, 1 from Central, 1 from Southern Germany and for 1 , it is only known that he came from Germany.

** There were 10 canons from Royal Prussia and 1 from the Diocese of Leslau/Włocławek.

37 It is possible that there were canons in Curonia in 1522, as Christoffer Sturm could be last mentioned in 1521, and Hermann Ronneberg perhaps first in the same year, but it is not certain (Hertwich E. Das Kurländische Domkapitel bis 1561. S. 185, 189).

${ }^{38}$ Lukas T. Tartu toomhärrad, 1224-1558. P. 83-100; Hertwich E. Das Kurländische Domkapitel bis 1561. S. 224-233. - Concerning the social origin, it is somewhat complicated to differentiate between lower nobility and town elite as their lifestyle could be quite similar. Here, their immediate family and the occupation of family members was taken into consideration, if possible. If a canon belonged to a Livonian noble family (such as Uexküll, Tiesenhausen, Lode, Wrangell etc.) then he was counted as a noble.

39 In 1522, there were 34 canons in Livonian chapters. The $35^{\text {th }}$ canon that joined before 1522 , was Johann Wetberg who was expelled from the chapter in 1516 and was reinstated during the 1530s (Herzog Albrecht von Preußen und Livland (1534-1540)... No.591, appendix 10; Arbusow L. Livlands Geistlichkeit vom Ende des 12. bis ins 16. Jahrhundert. Part 2. S. 138; Part 4. S. 235; Jaago K. 1543. aasta vasallidepäev Haapsalus // Läänemaa Muuseumi toimetised. Vol. 16 (2013). P. 131-136). 
Table 2. Social and geographical background of Livonian canons combined

\begin{tabular}{|l|c|c|c|c|}
\hline Social and geographical background & $\mathbf{1 5 2 2}$ & $\mathbf{1 5 2 3}-\mathbf{4 8}$ & $\mathbf{1 5 4 9 - 6 6}$ & $\mathbf{1 5 2 2 - 6 6}$ \\
\hline Livonian nobles & $11(31,4 \%)$ & $15(38,5 \%)$ & $10(25,6 \%)$ & $\mathbf{3 6}(\mathbf{3 1 , 9} \%)$ \\
\hline Livonian burghers & $10(28,6 \%)$ & $6(15,4 \%)$ & $3(7,7 \%)$ & $\mathbf{1 9}(\mathbf{1 6 , 8} \%)$ \\
\hline Nobles from Northern Germany & - & $2(5,1 \%)$ & $9(23,1 \%)$ & $\mathbf{1 1}(\mathbf{9 , 7} \%)$ \\
\hline Burghers from Germany & $6(17,2 \%)$ & $5(12,8 \%)$ & $6(15,4 \%)$ & $\mathbf{1 7}(\mathbf{1 5} \%)$ \\
\hline Burghers from Poland & $6(17,2 \%)$ & $3(7,7 \%)$ & $2(5,2 \%)$ & $\mathbf{1 1}(\mathbf{9 , 7} \%)$ \\
\hline $\begin{array}{l}\text { Social and/or geographical background } \\
\text { unknown }\end{array}$ & $2(5,7 \%)$ & $8(20,5 \%)$ & $9(23,1 \%)$ & $\mathbf{1 9}(\mathbf{1 6 , 8} \%)$ \\
\hline Total & $35(100 \%)$ & $39(100 \%)$ & $39(100 \%)$ & $\mathbf{1 1 3}(\mathbf{1 0 0} \%)$ \\
\hline
\end{tabular}

during 1549-1566 - then obvious changes can be identified (Tab. 1). Both the percentage of Livonians and burghers drop (from 60 to $33,3 \%$, and from 68,6 to $43,6 \%$, respectively), and by the end of the period, the nobility had clearly replaced burghers as the largest social group (53,8\%). If one combines the data for social and geographical background (Tab. 2), it appears that Livonian nobles remained the largest socio-geographical group throughout the period, but at the same time, the absolute number and percentage of local burghers had evidently fallen. There are clear changes in the numbers of canons coming outside Livonia as well. Formerly, quite noticeable number of burghers from Royal (Polish, or Western) Prussia decreased, and the number and percentage of both nobles and burghers from Germany rose.

One can offer several explanations for aforementioned trends. As most of Livonian and also Prussian burghers became Protestants, it could have been possible that they did not want to bind themselves to institutions which they saw as clearly Papist; and thus, they were replaced by the ones from Germany that were either Catholics, confessionally neutral or indifferent. The increase of the canons from the Empire could have been also connected with the activities of Livonian lords. Bishop Johannes von Münchhausen of Curonia and Osilia, who originated from the Diocese of Minden, distributed many canon seats in Curonia and Osilia to his favourites and relatives ${ }^{40}$. Margrave Wilhelm of Brandenburg-Ansbach, the Archbishop of Riga, tried to do the same in Riga ${ }^{41}$, but the Order - his main rival - was probably more successful in placing the relatives of the members of the Order (thus, German nobles) to the chapter seats there ${ }^{42}$.

40 At least six canons of Osilia and two of Curonia can regarded as his favourites (Maasing M. Kas Saare-Lääne toomkapiitlist sai 1524. aasta järel aadlikapiitel? P. 48, 56-57).

41 At least two of his officials became canons: Hieronymus Commerstadt in 1550 (Herzog Albrecht von Preußen und Livland (1540-1551)... No. 1501), and Jakob Meck in 1552 (Arbusow L. Sr. Livlands Geistlichkeit vom Ende des 12. bis ins 16. Jahrhundert. Part 2. S.67). In addition, he unsuccessfully tried to give a seat to Peter von Tiesenhausen, a canon of Dorpat (Herzog Albrecht von Preußen und Livland (15511557)... No. 1598).

${ }_{42}$ These relatives were: Kaspar von Galen in 1530 (Herzog Albrecht von Preußen und Livland (15251534)... No. 135); Johann van Munster in 1552 (Arbusow L. Sr. Livlands Geistlichkeit vom Ende des 12. 


\section{Cumulations}

Although canon law forbade a cleric to hold two or more ecclesiastic posts simultaneously, it was quite common for an ambitious churchman to collect or cumulate seats in many chapters, and hold them at the same time - thus obtaining multiple incomes and also obtaining a wider political and social influence ${ }^{43}$. The practice of cumulation was quite widespread in Livonia - especially the canons of Dorpat often held additional seats in Osilia ${ }^{44}$. In the period between 1522 and 1566, there were 37 chapter members of 113 canons that, according to the data, had at least two chapter seats (Tab. 3). Most of them (31) had at least two seats inside Livonia, but there were also five of them that had only one seat in Livonia and another or more outside the region. Many canons that had two or even three chapter seats in Livonia had also one or more seats elsewhere, and thus the total number of chapter members that had canonicates outside Livonia was 13. It is noteworthy that only one canon of Livonian origin - Johann Wetberg who was temporarily expelled from the chapter of Osilia - had a chapter seat outside Livonia, in Breslau (Wrocław). Other 12 canons originated either from Germany or Royal Prussia. The largest number of chapter seats held by one person was $6^{45}$, but most of the canons (28 of 37) had only two seats.

Table 3. Cumulations of the Livonian canons, 1522-1566

\begin{tabular}{|l|c|l|l|}
\hline All canons with cumulations & $\mathbf{3 7}(\mathbf{1 0 0} \%)$ & & $6(16,2 \%)$ \\
\hline $\begin{array}{l}\text { Canons with two or more } \\
\text { Livonian seats (inner- } \\
\text { Livonian cumulation) }\end{array}$ & $31(83,8 \%)$ & $\begin{array}{l}\text { Canons with one Livonian and one } \\
\text { or more outer-Livonian seats (outer- } \\
\text { Livonian cumulation) }\end{array}$ & $13(35,1 \%)$ \\
\hline $\begin{array}{l}\text { Canons with only inner- } \\
\text { Livonian seats }\end{array}$ & $24(64,9 \%)$ & $\begin{array}{l}\text { Canons with both Livonian (one or } \\
\text { more) and outer-Livonian seats (one or } \\
\text { more) }\end{array}$ & \\
\hline
\end{tabular}

Table 4. Percentages of the cumulations of Livonian canons by chapter

\begin{tabular}{|c|c|c|c|c|c|c|}
\hline Period & All chapters & Riga & Dorpat & Osilia & Curonia & Reval \\
\hline 1522 & $\begin{array}{c}17 \text { of } 35 \\
(48,6 \%)\end{array}$ & $\begin{array}{c}1 \text { of } 7 \\
(14,3 \%)\end{array}$ & $\begin{array}{c}11 \text { of } 16 \\
(68,8 \%)\end{array}$ & $\begin{array}{c}13 \text { of } 17 \\
(76,5 \%)\end{array}$ & $\begin{array}{c}1 \text { of } 1 \\
(100 \%)\end{array}$ & $\begin{array}{c}7 \text { of } 11 \\
(63,6 \%)\end{array}$ \\
\hline 1523 to 1548 & $\begin{array}{c}12 \text { of } 39 \\
(30,8 \%)\end{array}$ & $\begin{array}{c}1 \text { of } 8 \\
(12,5 \%)\end{array}$ & $\begin{array}{c}8 \text { of } 14 \\
(57,1 \%)\end{array}$ & $\begin{array}{c}6 \text { of } 14 \\
(42,9 \%)\end{array}$ & $\begin{array}{c}2 \text { of } 5 \\
(40 \%)\end{array}$ & $\begin{array}{c}5 \text { of } 8 \\
(62,5 \%)\end{array}$ \\
\hline 1549 to 1566 & $\begin{array}{c}8 \text { of } 39 \\
(20,5 \%)\end{array}$ & $\begin{array}{c}3 \text { of } 9 \\
(33,3 \%)\end{array}$ & $\begin{array}{c}3 \text { of } 11 \\
(27,3 \%)\end{array}$ & $\begin{array}{c}5 \text { of } 14 \\
(35,7 \%)\end{array}$ & $\begin{array}{c}1 \text { of } 3 \\
(33,3 \%)\end{array}$ & $\begin{array}{c}2 \text { of } 8 \\
(25 \%)\end{array}$ \\
\hline
\end{tabular}

bis ins 16. Jahrhundert. Part 2. P. 73); Johann von der Recke before 1555; and Goddert Fürstenberg before 1555 (for the two last, see: Herzog Albrecht von Preußen und Livland (1551-1557)... No. 1672-1673).

43 Cf. Fouquet G. Das Speyerer Domkapitel. P. 47-48.

44 Lukas T. Tartu toomhärrad. P. 77-80; Lukas T. Die Domherren des Bistums Ösel-Wiek 1228-1563. P. 231-234.

${ }^{45}$ Richard vom Walde had two Livonian seats - Osilia and Riga - and four abroad: Lübeck, Hamburg, Ratzeburg and Schwerin (Arbusow L. Sr. Livlands Geistlichkeit vom Ende des 12. bis ins 16. Jahrhundert. Part 4. P. 227; Prange W. Der Wandel des Bekenntnisses im Lübecker Domkapitel 1530-1600. S. 145146). 
Table 5. Chapters where Livonian canons had seats by the number of cumulations, 1522-1566

\begin{tabular}{|l|c|c|c|c|}
\hline \multicolumn{1}{|c|}{ Name } & $\mathbf{1 5 2 2}$ & $\mathbf{1 5 2 3}$ to $\mathbf{1 5 4 8}$ & $\mathbf{1 5 4 9}$ to 1566 & Total \\
\hline Osilia & $\mathbf{1 3}$ & $\mathbf{5}$ & $\mathbf{6}$ & $\mathbf{2 4}$ \\
\hline Dorpat & $\mathbf{1 1}$ & $\mathbf{8}$ & $\mathbf{3}$ & $\mathbf{2 2}$ \\
\hline Reval & $\mathbf{7}$ & $\mathbf{5}$ & $\mathbf{2}$ & $\mathbf{1 4}$ \\
\hline Lübeck & 1 & 2 & $\mathbf{3}$ & $\mathbf{5}$ \\
\hline Riga & $\mathbf{1}$ & $\mathbf{1}$ & $\mathbf{1}$ & $\mathbf{4}$ \\
\hline Curonia & $\mathbf{1}$ & $\mathbf{2}$ & $\mathbf{0}$ & $\mathbf{3}$ \\
\hline Ermland/Warmia & 3 & $\mathbf{0}$ & 1 & 2 \\
\hline Minden & 0 & 1 & 1 & 2 \\
\hline Verden & 0 & 1 & 1 & 1 \\
\hline Bremen & 0 & 0 & 0 & 1 \\
\hline Breslau/Wrocław & 1 & 0 & 0 & 1 \\
\hline Münster & 0 & 1 & 1 & 1 \\
\hline Hamburg & 0 & 0 & 1 & 1 \\
\hline Ratzeburg & 0 & 0 & 0 & 1 \\
\hline Schwerin & 0 & 0 & 1 & 1 \\
\hline Kolberg (collegiate chapter) & 1 & 0 & 1 & \\
\hline Xanten (collegiate chapter) & 0 & 0 & & 1 \\
\hline
\end{tabular}

${ }^{*}$ Collegiate chapters resembled the cathedral chapters, but they were located not around the cathedral but some other central church, and their social and political impact was somewhat lesser than the one of the cathedral chapters.

\begin{tabular}{|c|c|c|c|c|c|c|}
\hline Total & $\begin{array}{c}37 \text { of } 113 \\
(32,7 \%)\end{array}$ & $\begin{array}{c}5 \text { of } 24 \\
(20,8 \%)\end{array}$ & $\begin{array}{c}22 \text { of } 41 \\
(53,7 \%)\end{array}$ & $\begin{array}{c}24 \text { of } 45 \\
(53,3 \%)\end{array}$ & $\begin{array}{c}4 \text { of } 9 \\
(44,4 \%)\end{array}$ & $\begin{array}{c}14 \text { of } 27 \\
(51,9 \%)\end{array}$ \\
\hline
\end{tabular}

According to the available information, there was a clear decreasing trend in the habit of cumulation: almost half of Livonian canons held multiple seats in 1522, but only one fifth of the chapter members that entered Livonian chapters in 1549 or later did that (Tab. 4) ${ }^{46}$. It is also clear that cumulations were quite common in Osilia, Dorpat and Reval (more than $50 \%$ of canons of these chapters held multiple seats). Most often, they involved the following chapters: 11 persons were simultaneously in Osilia and Dorpat, 7 in Dorpat and Reval, 5 in Osilia and Reval, and 2 in all three aforementioned chapters. It is interesting to note that at least two canons of Dorpat used the seats in Reval as means of subsistence after the fall of Dorpat to the troops of Ivan IV in $1558^{47}$. In Riga and Curonia, the chapters of the Teutonic Order, the percentage of cumulations was clearly lower.

${ }^{46}$ Interestingly, all percentages of cumulations in individual chapters are higher than the general number. It is caused by the nature of how the cumulations were distributed between the chapters.

47 Both Jakob Lewenwolde and Wilhelm Todwen were canons of Dorpat in 1557-1558, and in 1560, they were mentioned as canons of Reval (Arbusow L. Sr. Livlands Geistlichkeit vom Ende des 12. bis ins 16. Jahrhundert. Part 4. P. 122-123, 218). 
However, the trend in Riga was contrary to others, as the number of cumulations was rising towards the end of the period.

Altogether, Livonian canons had cumulations in 11 different chapters outside Livonia, but in most of them, it occurred only once (Tab. 5). The exceptions are Lübeck (6 cases), Ermland/Warmia (3 cases), and Verden and Minden (both with 2 cases) ${ }^{48}$. As Livonia had close relations with both Northern Germany and Prussia, it is not very surprising that chapters of Lübeck and Ermland were popular amongst Livonian canons. But it also comes clear that connections with Ermland were more important before the Reformation - there were no cumulations between Livonian chapters and Ermland after the $1530 \mathrm{~s}^{49}$. On the other hand, the chapter of Lübeck became more prominent only during the 1550s and 1560s when four Livonian canons acquired its seats ${ }^{50}$. It seems that at least three of them - those who entered the chapter of Lübeck after the beginning of the Livonian War - utilized Lübeck as means of subsistence in a quite similar way as the two canons of Dorpat used the chapter of Reval. Finally, as both geographical origin of canons and their cumulations indicate the rise of the importance of German chapters, it seems possible to connect this to general intensification of the relations between Livonia and central institutions and regions of the Holy Roman Empire ${ }^{51}$.

\section{Religious stance of the chapters}

As it was indicated in the beginning, there is sufficient information to state that chapters of Germany were eminent opponents of the Reformation, and the same is claimed with respect to the ones of Livonia. For the latter, the evidence about this is mostly circumstantial. It is clear that the chapters generally followed their Bishops in public and political matters ${ }^{52}$, and thus they maintained Catholic stance at least publicly. Something more substantial can be said about the chapter of Riga as there is information about religious reform attempts from the reign of Archbishop Wilhelm von Brandenburg-Ansbach of Riga (1539-1563) ${ }^{53}$. From 1546 to 1547, Archbishop Wilhelm — who had probably supported Lutheranism for a long time - tried to introduce the Reformation in his

48 Two cumulations in Verden and Minden were caused by the fact that the seats were firstly held by future Bishop Johannes von Münchhausen of Osilia and Curonia; and then by his nephew Ulrich Behr who both originated from the diocese of Minden (Arbusow L. Sr. Livlands Geistlichkeit vom Ende des 12. bis ins 16. Jahrhundert. Part 1. P. 44; Part 2. P.72).

49 Before that time, cumulations with Lübeck and Ermland were quite characteristic of the chapters of Dorpat and Osilia (Lukas T. Tartu toomhärrad, 1224-1558. P. 78-79; Lukas T. Die Domherren des Bistums Ösel-Wiek 1228-1563. P.232).

50 These four were Augustin von Gethelen, Johann van Munster, Thomas Gabler, and Richard vom Walde (Prange W. Der Wandel des Bekenntnisses im Lübecker Domkapitel 1530-1600. S. 142, 144-146, 148).

${ }^{51}$ Maasing M. Livland und die Reichstage (1520-1555) // Livland - eine Region am Ende der Welt? Forschungen zum Verhältnis zwischen Zentrum und Peripherie im späten Mittelalter / eds A. Selart, M. Thumser. Köln, 2017. P. 283-312.

52 Cf. Piirimäe P. Staatenbund oder Ständestaat? Der livländische Landtag im Zeitalter Wolters von Plettenberg; Kreem J. Die Religionsfrage auf den livländischen Ständeversammlungen 1522-1558 // Preußen und Livland im Zeichen der Reformation / eds A. Mentzel-Reuters, K. Neitmann. Osnabrück, 2014. P. 183-197.

${ }^{53}$ For his religious politics, see: Müller U.: 1) Erzbischof Wilhelm von Riga und die Reformation in Livland 1535-1563; 2) Herzog Albrecht in Preußen und Erzbischof Wilhelm von Riga in ihren Bemühungen um die Evangelisierung der Landbevölkerung Livlands. 
Archbishopric and, if possible, in all Livonia ${ }^{54}$. This was probably inspired by the Reform attempt of Archbishop Hermann von Wied of Cologne (1515-1547), however, both of them failed in great part because of the opposition of their chapters ${ }^{55}$. The leadership of the chapter of Riga turned out to be decidedly Catholic: they were ready for a Catholic reform (just like the chapter of Cologne) but not for a Protestant one ${ }^{56}$. But only a decade later, the situation had changed completely. In 1558, the chapter of Riga decided to reform itself according to Lutheran principles. The Dean (German Domdekan) Friedrich Volckersam asked guidelines for this reform from Philipp Melanchthon, and reportedly was provided with them ${ }^{57}$. However, this attempt was unsuccessful, and its main instigator Dean Volckersam was killed in a battle at the beginning of $1559^{58}$. Three years later, Archbishop Wilhelm made an attempt to secularize the Archbishopric and liquidate the chapter. Then, the chapter proposed another plan for self-reform to preserve itself and become a Lutheran institution. But as the war raged on, and the Archbishop died early in 1563, both of these attempts remained unrealized. ${ }^{59}$

Concerning these conflicts between the Archbishop and his chapter, a question arises: were they directly caused by the religious matters; and moreover, could they be classified as confessional? It seems that only the conflict in the 1540s was caused by religious disagreements because later not only the Archbishop but also the majorities of canons were Protestant. And also in the 1540s, the conflict over the religious matters was rather brief and seemingly did not cause a lasting disruption between the Archbishop and the chapter: at the end of 1547, devotedly Catholic canon Augustin von Gethelen was a counsellor of the Lutheran Archbishop ${ }^{60}$. In general, one could say that political constraints did not follow the religious ones: for example, the Archbishop had also other Catholic confreres, and the Catholic Livonian Master Wolter von Plettenberg had a Lutheran Chancellor in the $1530 \mathrm{~s}^{61}$.

\section{Personal beliefs of the canons}

The Chapter of Riga provides also the richest information about canons' personal beliefs. Canon Jakob Knopken of Riga was the only chapter member in Livonia who had to give up his seat because of his Lutheran beliefs. In 1521, Jakob supported his brother Andreas - the first Reformer in Livonia - as Andreas began with his "evangelical" sermons. This caused the enmity of other canons, and in late 1522, Jakob decided to leave

${ }^{54}$ Karge P. Die Reformation und Gottesdienstordnung des Markgrafen-Erzbischofs Wilhelm von Riga vom März 1546 // Mitteilungen aus der livländischen Geschichte. 1924. Vol.22. P. 120-161.

55 Wied H. v. Einfältiges Bedenken. Reformationsentwurf für das Erzstift Köln von 1543 / eds H. Gerhards, W. Borth. Düsseldorf, 1972; Wolgast E. Hochstift und Reformation. Studien zur Geschichte der Reichskirche zwischen 1517 und 1648. S.91-99.

56 Herzog Albrecht von Preußen und Livland (1540-1551)... No. 1321, 1329, 1387, 1392, 1395, 1401.

57 Lange H. Die Familie von Meck in Livland. Vol. 1. Riga, 1913. P. 113; Herzog Albrecht von Preußen und Livland (1560-1564)... No. 2917; Lange H. Johannes Colerius. Ein Lebensbild aus der Zeit des Unterganges livländischer Selbständigkeit // Sitzungsberichte der Gesellschaft für Geschichte und Alterthumskunde der Ostseeprovinzen Russlands aus dem Jahre 1912 (1914). P. 105-136, here P. 107-108.

${ }^{58}$ Herzog Albrecht von Preußen und Livland (1557-1560)... No. 2364, 2396.

59 Herzog Albrecht von Preußen und Livland (1560-1564)... No. 2916, 3006; Lange H. Der Streit zwischen dem Erzbischof Wilhelm und dem Rigaschen Domkapitel...

${ }^{60}$ Herzog Albrecht von Preußen und Livland (1540-1551)... No. 1436.

${ }^{61}$ Cf. Herzog Albrecht von Preußen und Livland (1525-1534)... No. 248, 340, 351, 360, 363. 
Livonia. He tried to preserve his chapter seat but was excluded in 1523 and started his studies in Wittenberg a year later ${ }^{62}$. Other cases which are concerned with the personal beliefs of the canons are associated with the last decades of Medieval Livonia, and also come mostly from the chapter of Riga. As it became clear in the course of actions of the chapter at the beginning of the Livonian War, the leadership of Riga's chapter consisted of Lutherans ${ }^{63}$. There is also no doubt that Duke Christoph of Mecklenburg - the Coadjutor of Riga who was incorporated into the Chapter of Riga in 1557 - was a Lutheran ${ }^{64}$. Interestingly, Andreas Spill might have been only Calvinist in Livonian chapters: he was mentioned as a canon of Riga in 1566 and as a convert from Calvinism to Catholicism only shortly before his death in $1601^{65}$. But there are also examples of devout Catholics from the last decades of Medieval Livonia. All aforementioned four Livonian canons that joined the chapter of Lübeck in the 1550s and 1560s supported Catholicism ${ }^{66}$. Moreover, chronicler Tilmann Bredenbach mentioned two canons of Dorpat that clearly adhered to the Catholic confession in the $1550 \mathrm{~s}^{67}$.

In addition to Jakob Knopken, there were some cases when canons left Livonian chapters, but generally, these cannot be connected with the religious causes. The only indirect exception is Jordan Basedow. In 1527, he probably gave up his seat in Dorpat to follow secular or semi-secular lifestyle. On the other hand, he remained a member of the chapter of Lübeck, and, in 1535, he also became a member of city council there. However, his attempt to unite secular and clerical lifestyle was unsuccessful, and he was soon forced to abandon his seat in the chapter, and married shortly thereafter. By that time, he might have been a Lutheran but probably not yet in $1527^{68}$. Other examples were more directly connected with the marriage. In 1537, the Bishop and chapter of Osilia declared that Wolmar von Ungern was divested of the office of Provost because his election had

${ }^{62}$ Arbusow L. Jr. Die Einführung der Reformation in Liv-, Est- und Kurland. S. 241-243.

63 The last two Deans: Friedrich Volckersam (first mentioned as canon in 1554, Dean 1558-59) attempted to reform the chapter with the help of Melanchthon (Herzog Albrecht von Preußen und Livland (1560-1564)... No. 2917); and Jakob Meck (firstly mentioned as canon in 1552, Dean 1559-66) led the last reform attempt of the chapter (Lange H. Der Streit zwischen dem Erzbischof Wilhelm und dem Rigaschen Domkapitel...; Lange H. Die Familie von Meck in Livland. Vol. 2. Riga, 1931. P. 1-76).

${ }^{64}$ Bergengrün A. Herzog Christoph von Mecklenburg, letzter Koadjutor des Erzbistums Riga: ein Beitrag zur livländischen und mecklenburgischen Geschichte. Reval, 1898. P. 93, 310-313. P. 201.

${ }_{65}$ Arbusow L. Sr. Livlands Geistlichkeit vom Ende des 12. bis ins 16. Jahrhundert. Part 3. P. 69; Part 4.

66 Augustin von Gethelen was mentioned in 1537-53 in Riga, 1551-1557 in Curonia, and 1557-58 in Lübeck (Herzog Albrecht von Preußen und Livland (1534-1540)... No. 910; Prange W. Der Wandel des Bekenntnisses im Lübecker Domkapitel 1530-1600. S. 142; Berkholz G. Der rigasche Domherr Augustinus von Getelen // Mitteilungen aus dem Gebiete der Geschichte Liv-, Est- und Kurlands. 1868. Vol. 11. P.521-525). Johann van Munster was mentioned in 1552-66 in Riga, in the 1560s in Osilia, and in 1567-92 in Lübeck (Prange W. Der Wandel des Bekenntnisses im Lübecker Domkapitel 1530-1600. S. 148). Thomas Gabler was mentioned in 1554-62/65 in Osilia, and 1561/62-72 in Lübeck (Prange W. Der Wandel des Bekenntnisses im Lübecker Domkapitel 1530-1600. S. 144-145). Richard vom Walde was mentioned in 1559-about 1565 in Osilia, about 1565 in Riga, and in 1562-96 in Lübeck (Prange W. Der Wandel des Bekenntnisses im Lübecker Domkapitel 1530-1600. S. 145-146).

67 These were Wulfgang Sager (canon since 1538, Dean 1551-58) and Philipp von Olmen (canon 1551-58); the latter was the main informer of the chronicler (Bredenbach T. Historia belli Livonici qvod Magnvs Moscovitarvm dvx, contra Livones gessit. Per Tilmannum Bredenbachium conscripta. Vna cum breui narratione praeclarae eius victoriae qua paucis abhinc mensibus Lituani vicissim, contra Moscouitas potiti fuerunt. Antverpiae, 1564. P. 15, 40; Arbusow L. Sr. Livlands Geistlichkeit vom Ende des 12. bis ins 16. Jahrhundert. Part 2. P. 100; Part 4. P. 154, 250).

${ }^{68}$ Prange W. Der Wandel des Bekenntnisses im Lübecker Domkapitel 1530-1600. P. 19-20, 127. 
been uncanonical as he had been a minor ${ }^{69}$. However, the actual reasons were both political and private: Ungern was an enemy of Bishop Reinhold of Osilia (1530-1541), and he married the same year ${ }^{70}$. There were at least two other Livonian nobles that left the chapter themselves to marry ${ }^{71}$, but their religious affiliations remain as unclear as the ones of Ungern. Interestingly, there might have been also a canon who was lawfully married: according to Balthasar Russow, canon Johannes Blanckenborch of Reval was married in Germany, but he had to hide it in Livonia and claim that his wife was his concubine. ${ }^{72}$

There are some other instances when religious affiliation of a canon is implied. Earlier researchers stated that canons Matthias Unverferth and Hildebrand Lutke of Riga demonstrated noticeable curiosity about Protestantism and could have been rather pro-Protestant or somewhere in the middle ground between Catholics and Lutherans ${ }^{73}$. However, this statement seems to be not very plausible, as the books owned by Lutke were actually anti-Lutheran ${ }^{74}$, and both canons had the leading positions in the $1540 \mathrm{~s}$ when the chapter rejected the Lutheran reform plan of Archbishop Wilhelm. It is even more puzzling to indicate the religious allegiance of Friedrich von Ambten - a canon of Reval and Osilia, and later Bishop of Reval (1551-1557). Archbishop Wilhelm named him once reportedly Lutheran and a couple of years later - "total Papist"75. Additionally, the chronicler Johann Renner presented an anecdote, according to which, Ambten had once intended to become a preacher in Reval and asked how he should arrange the rehearse sermon - in an old (Catholic) or a new (Protestant) style. ${ }^{76}$ It can be that Ambten swayed between two confessions, tried to find a common ground between them, or was just a cold-blooded opportunist. However, at least until the 1550s, many Germans hoped for the reunion of the Western Church with the help of general or national church coun$\mathrm{cil}^{77}$, and it is quite possible that there could be Livonian canons that desired it as well.

\section{Conclusions}

Although there are some obvious gaps in currently available data about Livonian chapters and canons during the Reformation era, it seems that there is enough material to verify general trends concerning the characteristics discussed here. It also comes clear that the best information is currently available for the chapter of Riga - the numbers of its members were more steady in comparison to other Livonian chapters, and there is the richest knowledge about the activities and religious affiliations of the canons.

69 Arbusow L. Sr. Livlands Geistlichkeit vom Ende des 12. bis ins 16. Jahrhundert. Part 4. P. 223.

70 Arbusow L. Sr. Livlands Geistlichkeit vom Ende des 12. bis ins 16. Jahrhundert. Part 2. P. 131; Part 3. P.72; Ungern-Sternberg R. v., Russwurm C. Nachrichten über das Geschlecht Ungern-Sternberg. Vol. 1. Breslau, 1875. P. 193-195.

${ }^{71}$ Johann Volckersam left the chapter of Dorpat before 1550 and Johann Ascheberg the chapter of Osilia before 1557 (Arbusow L. Sr. Livlands Geistlichkeit... Part 1. P.77; Part 4. P. 10).

72 Russow B. Chronica. Der Prouinz Lyfflandt. Barth, 1584. F. 28r.

73 Cf. Karge P. Die Berufung des Markgrafen Wilhelm zum Koadjutor des Rigaschen Erzbichofs. Ein Betrag zur Reformationsgeschichte // Baltische Monatsschrift. 1906. Vol.61. P.117-156, here pp.130-132; Arbusow L. Sr. Livlands Geistlichkeit vom Ende des 12. bis ins 16. Jahrhundert. Part 4. P. 129, 222.

74 Arbusow L. Sr. Livlands Geistlichkeit vom Ende des 12. bis ins 16. Jahrhundert. Part 4. P. 129.

75 Herzog Albecht von Preußen und Livland (1540-1551)... No. 1312; Herzog Albecht von Preußen und Livland (1551-1557)... No. 1529.

76 Renner J. Livländische Historien / eds R. Hausmann, K. Höhlbaum. Göttingen, 1876. S. 154-155.

77 Mörke O. Die Reformation: Voraussetzungen und Durchsetzung. München, 2005. S. 53-57. 
Comparing the numbers of Livonian canons for the 1520s and the 1550s, it is possible to state that the general number did not decrease dramatically, and there were probably no important changes in chapters' position in local social and political spheres during the Reformation era. However, there were noticeable changes in canons' social and geographical background: the number of local burghers dropped drastically, as well as the importance of canons originating from Prussia. One can assume that it could have been connected with the domination of Protestantism in Livonian and Prussian towns and cities. However, if the significant rise of the number of noble-birth and German-origin canons from the 1540s might indicate that the chapter seats were mostly viewed as means of income, and the role of canons' religious commitment might have diminished, the data concerning the cumulations of chapter seats is at variance with it. The decrease in the cumulations might indicate that the principles of canon law might have been followed more strictly. Perhaps, the chapters tried to improve their inner discipline to be able to withstand the challenge of the Reformation better.

The activities of the chapter of Riga in the 1540s demonstrated it as a bulwark of the Catholicism according to Leonid Arbusow Jr., but this trend was certainly not continuous as it is shown by the actions of the chapter during the beginning of the Livonian War. It appears that the majority of the canons of Riga were supporting Protestantism by the beginning of the war, and that this turn must have taken place during the 1550s. Unfortunately, the information is too scarce for other Livonian chapters to assess religious stance there.

The survey of canons' personal beliefs indicates that, except for one canon, probably no other left the chapter because of religious convictions. There were a slightly increasing number of canons that left the chapter to marry, but this cannot be directly connected with religion. There are no signs of religious tensions inside or between the chapters, and it might as well be that most of the canons, irrespective of their personal confessional preferences, were waiting for a general solution to the religious divide and rather hoped for the reunion of Western Church.

As there are no other signs of serious religious conflicts in Livonia generally, it seems justified to suggest that strict religious differentiation reached the region only during the Livonian War when the old political structures collapsed and new borders - political, ideological, and also confessional - were drawn by Russia, Poland-Lithuania, Denmark and Sweden. Moreover, it can be maintained that truly confessionalist conflicts occurred in the region even later, only since the 1580s when the Jesuits started the Counter-Reformation in Polish Livonia, and the Swedes began to implement strict Protestantism in the Province of Estonia.

\section{References}

Arbusow L. Jr. Die Einführung der Reformation in Liv-, Est- und Kurland. Leipzig, Heinsius, 1921, 851 p.

Arbusow L. Sr. Livlands Geistlichkeit vom Ende des 12. bis ins 16. Jahrhundert. Jahrbuch für Genealogie, Heraldik und Sphragistik 1900, 1902, Teil 1, S.33-80.

Arbusow L. Sr. Livlands Geistlichkeit vom Ende des 12. bis ins 16. Jahrhundert. Jahrbuch für Genealogie, Heraldik und Sphragistik 1901, 1902, Teil 2, S. 1-160.

Arbusow L. Sr. Livlands Geistlichkeit vom Ende des 12. bis ins 16. Jahrhundert. Jahrbuch für Genealogie, Heraldik und Sphragistik 1902, 1904, Teil 3, S.39-134.

Arbusow L.Sr. Livlands Geistlichkeit vom Ende des 12. bis ins 16. Jahrhundert. Jahrbuch für Genealogie, Heraldik und Sphragistik 1911-13, 1914, Teil 4, S.1-432. 
Bergengrün A. Herzog Christoph von Mecklenburg, letzter Koadjutor des Erzbistums Riga: ein Beitrag zur livländischen und mecklenburgischen Geschichte. Reval, Kluge, 1898, 324 S.

Berkholz G. Der rigasche Domherr Augustinus von Getelen. Mitteilungen aus dem Gebiete der Geschichte Liv-, Est- und Kurlands, 1868, Bd.11, S.521-525.

Braun H. A. Das Domkapitel zu Eichstätt: von der Reformationszeit bis zur Säkularisation (1535-1806): verfassung und Personalgeschichte. Stuttgart, Steiner, 1991, 615 S.

Fouquet G. Das Speyerer Domkapitel im Späten Mittelalter (ca. 1350-1540): adlige Freundschaft, fürstliche Patronage und päpstliche Klientel. Bd.1. Mainz, Gesellschaft für Mittelrheinische Kirchengeschichte, $1987,302 \mathrm{~s}$

Glauert M. Die Bindung des Domkapitels von Riga an die Regel des Deutschen Ordens. Die Domkapitel des Deutschen Ordens in Preußen und Livland. Hrsg. R. Biskup, M. Glauert. Münster, Aschendorff, 2004, ss. 269-316.

Hertwich E. Das Kurländische Domkapitel bis 1561. Die Domkapitel des Deutschen Ordens in Preußen und Livland. Hrsg. R. Biskup, M. Glauert. Münster, Aschendorff, 2004, S. 147-267.

Jaago K. 1543. aasta vasallidepäev Haapsalus. Läänemaa Muuseumi toimetised, 2013, vol. 16, pp.131-136.

Kallmeyer T. Geschichte der Habits-Veränderungen des Rigischen Domcapitels, nebst Untersuchungen über streitige Gegenstände in derselben, mit urkundlichen Beilagen. Mitteilungen aus dem Gebiete der Geschichte Liv-, Est- und Kurlands, 1842, Bd.2, S. 197-340.

Karge P. Die Berufung des Markgrafen Wilhelm zum Koadjutor des Rigaschen Erzbichofs. Ein Betrag zur Reformationsgeschichte. Baltische Monatsschrift, 1906, Bd.61, S.117-156.

Karge P. Die Reformation und Gottesdienstordnung des Markgrafen-Erzbischofs Wilhelm von Riga vom März 1546. Mitteilungen aus der livländischen Geschichte, 1924, Bd.22, S. 120-161.

Kreem J. Der Deutsche Orden in Livland unter Hermann von Brüggenei: Bemerkungen zu Regierungspraxis und Religionspolitik. Ordines Militares, 2011, Bd. 16, S.303-315.

Kreem J. Die Religionsfrage auf den livländischen Ständeversammlungen 1522-1558. Preußen und Livland im Zeichen der Reformation. Eds A.Mentzel-Reuters, K. Neitmann. Osnabrück, Fibre, 2014, S. 183197.

Lange H. Der Streit zwischen dem Erzbischof Wilhelm und dem Rigaschen Domkapitel wegen der erledigten Propstei 1561. Mitteilungen aus dem Gebiete der Geschichte Liv-, Est- und Kurlands, 1911, Bd.21, S. 30-83.

Lange H. Die Familie von Meck in Livland, Bd. 1. Riga, Hansa Print., 1913, 463 S.

Lange H. Die Familie von Meck in Livland, Bd. 2. Riga, Harald Lange Private Print., 1931, 300 S.

Lange T. Zwischen Reformation und Untergang Alt-Livlands: Der Rigaer Erzbischof Wilhelm von Brandenburg im Beziehungsgeflecht der livländischen Konföderation und ihrer Nachbarländer, Bd. 1-2. Hamburg, Dr. Kovač, 2014, 786 S.

Loit A. Reformation und Konfessionalisierung in den ländlichen Gebieten der baltischen Lande von ca. 1500 bis zum Ende der schwedischen Herrschaft. Die baltischen Lande im Zeitalter der Reformation und Konfessionalisierung: Livland, Estland, Ösel, Ingermanland, Kurland und Lettgallen: Stadt, Land und Konfession 1500-1721, Bd.1. Hrsg. M. Asche, W. Buchholz, A. Schindling. Münster, Aschendorff, 2009, S. 49-217.

Lukas T. Die Domherren des Bistums Ösel-Wiek 1228-1563. Saare-Lääne piiskopkond. Artiklid LääneEesti keskajast = Bistum Ösel-Wiek: Artikelsammlung zum Mittelalter in Westestland. Ed. by U.Paras. Haapsalu, Läänemaa Muuseum, 2004, pp. 211-244.

Lukas T. Tartu toomhärrad, 1224-1558. Tartu, Tartu Universty Press, 1998, 278 p.

Maasing M. Kas Saare-Lääne toomkapiitlist sai 1524. aasta järel aadlikapiitel? Läänemaa Muuseumi toimetised, 2018, vol.21, pp.33-62.

Maasing M. Livland und die Reichstage (1520-1555). Livland - eine Region am Ende der Welt? Forschungen zum Verhältnis zwischen Zentrum und Peripherie im späten Mittelalter. Hrsg. A. Selart, M. Thumser. Köln, Böhlau, 2017, S. 283-312.

Maasing M. The Role of the Bishops in the Livonian Political System (in the First Half of the 16th Century). Tartu, Tartu University Press, 2016, 316 p.

Mettig C. Bemerkungen zur Geschichte des Rigaschen Domkapitels. Sitzungsberichte der Gesellschaft für Geschichte und Altertumskunde der Ostseeprovinzen Russlands aus dem Jahre 1911, 1913, S. 386-394.

Mettig C. Zur Verfassungsgeschichte des Rigaschen Domcapitels. Mitteilungen aus dem Gebiete der Geschichte Liv-, Est- und Kurlands, 1880, Bd. 12, S. 509-537.

Mörke O. Die Reformation: Voraussetzungen und Durchsetzung. München, Oldenbourg, 2005, $174 \mathrm{~s}$.

Müller U. Erzbischof Wilhelm von Riga und die Reformation in Livland 1535-1563. Preußen und Livland im Zeichen der Reformation. Hrsg. A. Mentzel-Reuters, K. Neitmann. Osnabrück, Fibre, 2014, S. 241-343. 
Müller U. Herzog Albrecht in Preußen und Erzbischof Wilhelm von Riga in ihren Bemühungen um die Evangelisierung der Landbevölkerung Livlands, Bd. 1. Preußenland, N. F., 2014, Bd. 5, S.49-97.

Müller U. Herzog Albrecht in Preußen und Erzbischof Wilhelm von Riga in ihren Bemühungen um die Evangelisierung der Landbevölkerung Livlands, Bd. 2-3. Preußenland, N. F., 2015, Bd. 6, S.43-99.

Piirimäe P. Staatenbund oder Ständestaat? Der livländische Landtag im Zeitalter Wolters von Plettenberg. Forschungen zur baltischen Geschichte, 2013, Bd. 8, S. 40-80.

Piirimäe P. Ständischer Dualismus und territoriale Verselbständigung. Über der Verfassung des Bistums Dorpat im letzten Jahrhundert Alt-Livlands. Zur Geschichte der Deutschen in Dorpat. Hrsg. H. Piirimäe, C. Sommerhage. Tartu, Tartu University Press, 1998, S. 38-62.

Prange W. Der Wandel des Bekenntnisses im Lübecker Domkapitel 1530-1600. Lübeck, Schmidt-Römhild, 2007, 188 S.

Raudkivi P. Der livländische Landtag: zur Entstehung einer mittelalterlichen Institution. Berlin, Lit, 2018, 149 S.

Russow B. Chronica. Der Prouintz Lyfflandt. Barth, A. Seitner, 1584, 136 f.

Ungern-Sternberg R.v., Russwurm C. Nachrichten über das Geschlecht Ungern-Sternberg. Vol. 1. Breslau, Jungfer Print, 1875, 398 S.

Wolgast E. Hochstift und Reformation. Studien zur Geschichte der Reichskirche zwischen 1517 und 1648. Stuttgart, Steiner, 1995, 375 S.

Статья поступила в редакцию 30 декабря 2018 г. Рекомендована в печать 10 июня 2019 г. Received: December 30, 2018

Accepted: June 10, 2019 